\title{
Н.Н. Веселовська
}

\section{ЧИННИКИ РИЗИКУ СУДИННОЙ ПАТОЛОГІЇ ОРГАНА ЗОРУ У ХВОРИХ НА ЦУКРОВИЙ ДІАБЕТ}

\author{
Київський міський офтальмологічний центр КМКЛ №1, Київ
}

\section{ВСТУП}

Судинно-ендокринна патологія органа зору залишається першою причиною погіршення зору та сліпоти у світі, зокрема в Україні, серед якої насамперед визначають діабетичну ретинопатію (ДР) і глаукому $[1,5,8,11,12]$. За даними Міжнародної діабетичної федерації (IDF), кількість хворих на цукровий діабет (ЦД) на планеті 2011 року досягла 366 млн. із тенденцією до подальшого стрімкого зростання. Впровадження нових удосконалених методів цукрознижувальної терапії сприяє збільшенню тривалості життя хворих на ЦД, що, відповідно, призводить до зростання розповсюдженості ускладнень ЦД, у тому числі офтальмологічних. Поряд із цим, у світі, зокрема в України та Росії, спостерігається і негативна тенденція до поширення серцево-судинної патології та її ускладнень, включаючи порушення функцій органа зору [2, 4, 6, 7]. За даними Центру медичної статистики МОЗ України, захворюваність на глаукому та діабетичну ретинопатію лише минулого року збільшилася на 1,3\% і 2,0\% відповідно [10]. Своєрідну епідемію означених хронічних неінфекційних захворювань значною мірою пов'язано зі способом життя, що формує певні біологічні чинники ризику [2, 6, 7]. Відомо, що серед основних чинників ризику втрати зору у хворих на ЦД і серцево-судинну патологію артеріальна гіпертензія посідає провідне місце $[12,14,15]$. Крім того, дослідження останніх років дозволили встановити, що прогресування втрати зору внаслідок діабетичної ретинопатії у хворих на Цд 2-го типу можливо призупинити за допомогою "жорсткого" контролю АТ [15].

За даними сучасних експериментальних, клінічних та епідеміологічних досліджень було визначено певні індивідуальні чинники ризику розвитку та прогресування загальних судинних та ендокринних захворювань, зумовлені способом життя, умовами довкілля та генетичними особливостями. Серед чинників, пов'язаних зі способом життя, виділяють брак фізичної активнос- ті, незбалансоване харчування, шкідливі звички. Проте встановлено, що їх корекція може сприяти зниженню індивідуального ризику за рахунок впливу на такі біологічні чинники, як надмірна маса тіла, артеріальна гіпертензія, порушення жирового та вуглеводного обмінів [2, $4,7,13,14]$. Дослідження останніх 10 років визначили інформативність цифрових методів обстеження ока, у першу чергу оптико-когерентної томографії сітківки, у діагностиці ранніх змін сітківки у хворих на ЦД на передкліничному рівні [3]. Натомість у літературі відсутні дані про комплексну дію деяких із зазначених вище чинників ризику на морфо-функціональний стан сітківки.

Мета роботи - визначення чинників ризику судинної патології органа зору на підставі аналізу результатів комплексного обстеження хворих на цд.

\section{МАТЕРІАЛ I МЕТОДИ}

Обстежено 140 осіб (280 очей) віком 4060 років: група 1 - 120 хворих (240 очей) із цД 2-го типу та група 2 - 20 практично здорових осіб (40 очей) - контрольна. Тривалість ЦД складала до 5 років. Відповідно до стану центральної зони макулярної ділянки сітківки за даними товщини сітківки макулярної ділянки (ТСМД) по результатах оптико-когерентної томографії (ОКТ) сітківки пацієнтів контрольної групи групу 1 було розподілено на дві підгрупи: підгрупа $1 \mathrm{~A}$, до якої включили пацієнтів, рівень ТСМД у яких не виходив за межі інтервалу ТСМД контрольної групи (ТСМД<180,0 мкм), і підгрупа 1В, до якої увійшли пацієнті з більшим рівнем ТСМД відносно контролю, тобто з ТСМД>180,0 мкм. До дослідження не включали пацієнтів із високими ступенями аномалій рефракції та супутньою патологією органа зору для виключення побічного впливу означених станів на результати офтальмологічного обстеження, що включало: візометрію, передню та задню біомікроскопію, тонометрію, офтальмоскопію з фо- 
Розподіл обстежених за гостротою зору, рефракцією, внутрішньоочним тиском, n (\%)

\begin{tabular}{l|c|c}
\hline \multicolumn{1}{c|}{ Показник } & \multicolumn{1}{c|}{$\begin{array}{c}\text { Група 1 } \\
\mathbf{n = 1 2 0}\end{array}$} & $\begin{array}{c}\text { Група 2 } \\
\mathbf{n = 2 0}\end{array}$ \\
\hline Г3 без корекції 0,5-0,7 & $54(45)^{*}$ & $6(30)$ \\
Г3 без корекції 0,9-1,0 & $66(55)^{*}$ & $14(70)$ \\
ГЗ із окулярами $0,9-1,0$ & $120(100)$ & $20(100)$ \\
\hline М<3,0 D & $36(30)^{*}$ & $4(20)$ \\
Hт<2,0 D & $18(15)^{*}$ & $2(10)$ \\
\hline ВОТ мм рт. ст. $(\mathrm{M} \pm \mathrm{m})$ & $16,0 \pm 1,2$ & $16,0 \pm 1,7$ \\
\hline
\end{tabular}

Примітка: * - вірогідна різниця $(p<0,05)$.

тореєстрацією очного дна, оптико-когерентну томографію сітківки. Кількісно-якісний аналіз нейроархітектоніки макулярної ділянки сітківки здійснювали на OKT-Stratus-3000 фірми "Ziess" у режимах сканування "Товщина макули", "Карта сітківки" та "Таблиці товщини та об'єму сітківки". Загальне обстеження хворих включало дослідження АТ, електрокардіограми, загального аналізу сечі, глікемії натще, лейкоцитарної формули (ЛФ), біохімічного аналізу крові (холестерин, холестерин-ЛПНЩ, тригліцериди (ТГ), коефіцієнта атерогенності (КА), глікованого гемоглобіну (HbA1c) і визначення індексу маси тіла (IMT), фізичної активності (ФА), психоемоційного напруження (ПЕН) і шкідливої звички тютюнопаління за даними опитування.

\section{РЕЗУЛЬТАТИ ТА ОБГОВОРЕННЯ}

Результати офтальмоскопічного обстеження очного дна осіб груп 1 і 2 свідчили про відсутність ознак патологічних змін сітківки, характерних для діабетичної ретинопатії (ДР), діабетичної макулопатії (ДМП) та інших захворювань сітківки та зорового нерва (ЗН). Вхідний рівень гостроти зору коливався у межах 0,5-0,7 без корекції та 0,8-1,0 із корекцією. Частка осіб із міопією (М) і гіперметропією (Hm) слабкого ступеня у групах 1 і 2 складала 45\% і 30\% відповідно (табл. 1).

Як видно з таблиці 2, значення ТСМД у хворих групи 1 були в інтервалі 170,0-198,0 мкм (середній рівень - 183,67ะ3,33 мкм). У підгрупі

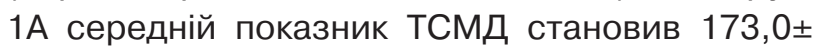
$\pm 4,9$ мкм і суттєво не відрізнявся від середнього показника ТСМД у групі контролю $(172,0 \pm$ $\pm 3,15$ мкм). У хворих підгрупи 1В середній рівень ТСМД складав 198,0 2,13 мкм і на 13,1\% та 6,5\% перевищував рівень ТСМД в осіб групи 2 та групи 1 відповідно.
Таблиця 2

\section{Аналіз показників ТСМД (мкм) за результатами ОКТ}

\begin{tabular}{|c|c|}
\hline Група (n) & $\begin{array}{c}\text { ТСМД, } \\
\text { межі коливань }(\mathrm{M} \pm \mathrm{m})\end{array}$ \\
\hline Група 1 (120) & $170,0-205,0(183,67 \pm 3,33)^{\star}$ \\
\hline Підгрупа 1A (80) & $170,0-180,0(173,0 \pm 4,9)$ \\
\hline Підгрупа 1B (40) & $183,0-205,0(198,0 \pm 2,13)^{*+}$ \\
\hline Група 2 (20) & $168,0-182,0(172,0 \pm 3,15)$ \\
\hline
\end{tabular}

Примітка: * - вірогідна різниця з контрольною групою $(p<0,05) ;^{+}$- вірогідна різниця з групою $1(p<0,05)$.

Наведені дані свідчать про вірогідне збільшення товщини сітківки макулярної зони у хворих підгрупи 1В. Поряд із цим, жодних ознак порушення нейроархітектоніки сітківки цієї зони на ретинальних томограмах не виявлено (рис. 1, 2). Отже, у 40 хворих на ЦД, які склали підгрупу 1В, були відсутні клінічні прояви ДР та якісні морфологічні зміни у структурі сітківки макулярної зони, але за даними прижиттєвого комп'ютерного морфологічного аналізу у цих пацієнтів було визначено вірогідне збільшення товщини сітківки, що певною мірою може служити ознакою передклінічних змін сітківки у хворих на ЦД, ранню діагностику яких на стадії препатології можна здійснити методом прижиттєвого комп'ютерного морфологічного аналізу.

Загальне обстеження виявило вікові зміни міокарда у хворих і збільшення кількості пацієнтів із підвищенням АТ до $38,3 \%$ у групі 1 , переважно за рахунок пацієнтів із підгрупи 1В, в якій 39 із 40 хворих $(97,5 \%)$ мали підвищений АТ. Отже, частка хворих із підвищеним АТ у групі 1 і підгрупі 1В значно, майже у 7 і 20 разів відповідно, перебільшувала частку таких хворих (5,0\%) у контрольній групі.

Результати загального аналізу сечі свідчили про відсутність захворювань сечової системи. 


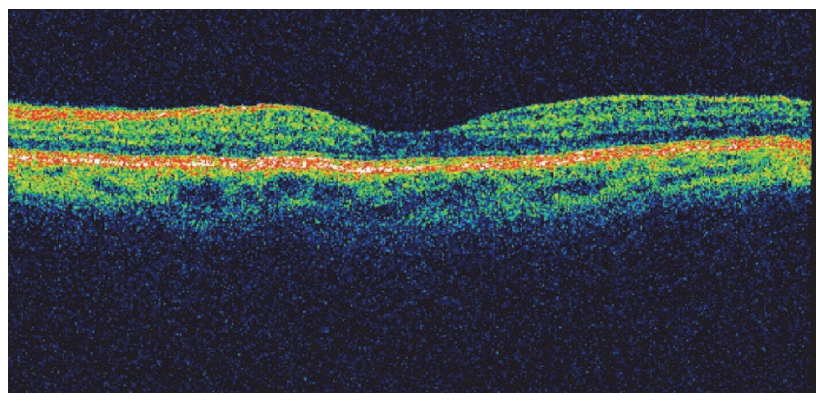

Рис. 1. Томограма макулярної зони сітківки хворого М. (ЦД 2-го типу): ТСМД - 170,0 мКм.

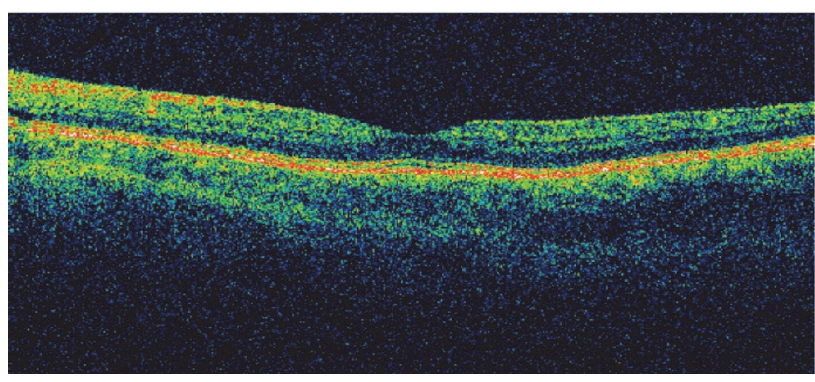

Рис. 2. Томограма макулярної зони сітківки хворого Д. (ЦД 2-го типу): збільшення ТСМД до 198,0 мкм без порушення нейроархітектоніки.

Вивчення лейкоцитарної формули виявило незначне збільшення кількості нейтрофілів сегментоядерних у хворих підгрупи 1В порівняно з особами груп 1, 2 і підгрупи 1А у межах 1\% (табл. 3).

Розподілення учасників дослідження за відхиленнями біохімічних показників від фізіологічної норми наведено у таблиці 4. У підгрупі 1В нестабільний рівень глюкози натще визначено у $77,5 \%$ випадків (збільшення - у 27,5\%, зменшення - у 50\%), що майже вдвічі більше за аналогічні показники для групи 1 у цілому. Збільшення показників холестерину, ЛПНЩ, ТГ і КА виявлено у значно більшої кількості хворих підгрупи 1В (62,5\%, 35,5\%, 60,0\% і 22,5\% відповідно) порівняно 3 групами 1 і 2 (табл. 4). Частка хворих зі збільшеним рівнем HbA1c у підгрупі 1В (12,0\%) була також майже вдвічі більшою, ніж у групі 1 у цілому, тобто, у підгрупі 1В значно більша кількість хворих перебували у стані нестабільної компенсації ЦД. За результатами додаткового обстеження та незалежного опитування, понад 50\% хворих на ЦД (група 1) мали надмірну вагу (IMT

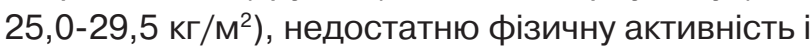
психоемоційне напруження (55,0\%, 58,3\% і 76,7\% відповідно). У підгрупі 1В іх частки становили 60\%, 90\% і 95\%, що майже утричі перевищило відповідні показники контрольної групи.

Тютюнопаління відзначено у практично однакових часток хворих на ЦД і пацієнтів контрольної групи (23,0\% і 20,0\% відповідно). Натомість серед 40 пацієнтів підгрупи 1В 30,0\% хворих малу таку шкідливу звичку, що майже на 10\% більше, ніж у групах 1 і 2.

\section{вИСНОвки}

1. За даними кількісного прижиттєвого морфологічного аналізу (ОКТ), у 30\% хворих на ЦД 2-го типу наявне збільшення товщини сітківки макулярної ділянки без порушення нейроархітектоніки та без клінічних ознак судинної патології очного дна.

2. Підвищення артеріального тиску, нестабільний рівень глюкози натще, підвищений рівень ліпідних фракцій (холестерину, ЛПНЩ, ТГ, KA), поряд зі збільшеним IMT на тлі недостатньої фізичної активності та психоемоційного напруження створюють умови підвищеного ризику розвитку судинної патології органа зору у хворих на цд.

\section{Порівняльний аналіз результатів клінічного обстеження крові} (лейкоцитарна формула, $\mathrm{M} \pm \mathrm{m}$ )

\begin{tabular}{|c|c|c|c|c|}
\hline Показник & $\begin{array}{l}\text { Група } 1 \\
(n=120)\end{array}$ & $\begin{array}{c}\text { Підгрупа 1А } \\
(\mathrm{n}=80)\end{array}$ & $\begin{array}{c}\text { Підгрупа 1B } \\
(n=40)\end{array}$ & $\begin{array}{c}\text { Група } 2 \\
(n=20)\end{array}$ \\
\hline Лейкоцити (×10\%/л) & $5,67 \pm 0,33$ & $5,24 \pm 0,42$ & $5,94 \pm 0,44$ & $5,32 \pm 0,35$ \\
\hline Нейтрофіли паличкоядерні (\%) & $2,90 \pm 0,48$ & $2,2 \pm 0,78$ & $2,98 \pm 0,86$ & $2,70 \pm 0,7$ \\
\hline Нейтрофіли сегментоядерні (\%) & $57,60 \pm 4,88$ & $62,70 \pm 3,42$ & $68,70 \pm 3,12^{*}$ & $56,70 \pm 3,51$ \\
\hline Базофіли (\%) & $0,72 \pm 0,24$ & $0,90 \pm 0,0$ & $1,00 \pm 0,0$ & $0,64 \pm 0,22$ \\
\hline Еозинофіли (\%) & $3,78 \pm 0,72$ & $3,24 \pm 0,89$ & $4,02 \pm 0,98$ & $3,95 \pm 0,96$ \\
\hline Моноцити (\%) & $8,05 \pm 0,75^{*}$ & $8,45 \pm 0,89$ & $9,02 \pm 0,89$ & $8,68 \pm 0,36$ \\
\hline Лімфоцити (\%) & $31,30 \pm 3,45$ & $39,90 \pm 2,88$ & $32,60 \pm 2,48$ & $31,00 \pm 3,04$ \\
\hline
\end{tabular}

Примітка: * - вірогідна різниця з контрольною групою $(p<0,05) ;{ }^{+}$- вірогідна різниця з групою 1 (p<0,05). 
Результати біохімічного обстеження крові та анкетування, $\mathbf{n}(\%)$

\begin{tabular}{|c|c|c|c|c|}
\hline Показник & $\begin{array}{l}\text { Група } 1 \\
(n=120)\end{array}$ & $\begin{array}{c}\text { Підгрупа 1А } \\
(n=80)(1 A / 1)\end{array}$ & $\begin{array}{c}\text { Підгрупа 1B } \\
(n=40)(1 B / 1)\end{array}$ & $\begin{array}{c}\text { Група } 2 \\
(n=20)\end{array}$ \\
\hline $\begin{array}{l}\text { АТ сист. } \\
\geq 140 \text { мм рт. ст. }\end{array}$ & $\begin{array}{l}46 * \\
38,3 \%\end{array}$ & $\begin{array}{l}7 \\
5,8-8,75(\%)\end{array}$ & $\begin{array}{l}39{ }^{*+} \\
32,5 \%-97,5(\%)\end{array}$ & $\begin{array}{l}1 \\
5 \%\end{array}$ \\
\hline $\begin{array}{l}\text { Глюкоза натие } \\
\leq 3,89 \text { ммоль/л }\end{array}$ & $\begin{array}{l}32.7 ? \\
26,7 \%\end{array}$ & $\begin{array}{l}12 \\
10,0 \%-15(\%)\end{array}$ & $\begin{array}{l}20 *+2 \\
16,7 \%-50(\%)\end{array}$ & $\begin{array}{l}0 . \\
0 .\end{array}$ \\
\hline $\begin{array}{l}\text { Глюкоза натще } \\
\geq 5,83 \text { ммоль/л }\end{array}$ & $\begin{array}{l}22 * \\
18,3 \%\end{array}$ & $\begin{array}{l}1 \\
0,8-1,25(\%)\end{array}$ & $\begin{array}{l}11^{\star^{+}} \\
9,2 \%-27,5(\%)\end{array}$ & $\begin{array}{l}0 \\
0\end{array}$ \\
\hline 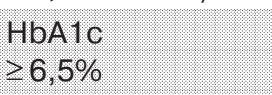 & $\begin{array}{l}8 \\
6,7 \% ? ? ?\end{array}$ & $\begin{array}{l}3 \\
2,5-3,75(\%)\end{array}$ & $\begin{array}{l}5 * \cdots \\
4,2 \%-12,0,(\%)\end{array}$ & $\begin{array}{l}0 \\
0\end{array}$ \\
\hline $\begin{array}{l}\text { Холестерин } \\
\geq 4,8 \text { ммоль/л }\end{array}$ & $\begin{array}{l}26 * \\
20,0 \%\end{array}$ & $\begin{array}{l}1 \\
0,8-1,25(\%)\end{array}$ & $\begin{array}{l}25^{*+} \\
20,8 \%-62,5(\%)\end{array}$ & $\begin{array}{l}1 \\
5 \%\end{array}$ \\
\hline $\begin{array}{l}\text { лПнщ } \\
\geq 2,2 \text { ммоль/л }\end{array}$ & $\begin{array}{l}20 \% \\
16,7 \%\end{array}$ & $\begin{array}{l}6 \\
5,0-7,5(\%)\end{array}$ & $\begin{array}{l}14 *+\cdots \\
11,7 \%-35,0(\%)\end{array}$ & $\begin{array}{l}1 \\
5 \%\end{array}$ \\
\hline $\begin{array}{l}\text { Тригліцериди } \\
>2,1 \text { ммоль/л }\end{array}$ & $\begin{array}{l}16 * \\
13,3 \%\end{array}$ & $\begin{array}{l}5 \\
4,2-6,25(\%)\end{array}$ & $\begin{array}{l}24^{*+} \\
9,2-60,0(\%)\end{array}$ & $\begin{array}{l}1 \\
5 \%\end{array}$ \\
\hline $\begin{array}{l}\mathrm{KA} \\
>3,0\end{array}$ & $\begin{array}{l}12 \% \\
10,0 \%\end{array}$ & $3,5-3,5(\%)$ & $\begin{array}{l}9 \times+2 \\
7,5-22,5(\%)\end{array}$ & $\begin{array}{l}0 . \\
0\end{array}$ \\
\hline $\begin{array}{l}\text { IMT } \\
25-29,9 \text { кг/м }\end{array}$ & $\begin{array}{l}66 * \\
55,0 \%\end{array}$ & $\begin{array}{l}28 \\
23,3-35(\%)\end{array}$ & $\begin{array}{l}24^{\star+} \\
31,7-60(\%)\end{array}$ & $\begin{array}{l}4 \\
20,0 \%\end{array}$ \\
\hline HФA & $\begin{array}{l}70 * ? \\
58,3 \%\end{array}$ & $\begin{array}{l}34 \\
28,3-42,5(\%)\end{array}$ & $\begin{array}{l}36 * * \\
30,0-90(\%)\end{array}$ & $\begin{array}{l}6 \\
30,0 \%\end{array}$ \\
\hline ПЕН & $\begin{array}{l}92 * \\
76,7 \%\end{array}$ & $\begin{array}{l}54 \\
45,0-67,5(\%)\end{array}$ & $\begin{array}{l}38^{\star+} \\
31,7-95,0(\%)\end{array}$ & $\begin{array}{l}6 \\
30,0 \%\end{array}$ \\
\hline Тютюнопаління & $\begin{array}{l}28 \\
23,3 \%\end{array}$ & $\begin{array}{l}16 \\
13,3-20,0(\%)\end{array}$ & $\begin{array}{l}12 *+ \\
10,0-30,0(\%)\end{array}$ & $\begin{array}{l}4 \\
20,0 \%\end{array}$ \\
\hline
\end{tabular}

Примітка: НФА - недостатня фізична активність; ПЕН - психоемоційне напруження; * - вірогідна різниця з контрольною групою (p<0,05); + - вірогідна різниця з групою 1 ( $p<0,05)$.

3. Оптико-когерентна ретинальна томографія є високоінформативним методом прижиттєвого морфологічного аналізу, який дозволяє діагностувати появу перших судинних змін сітківки та зорового нерва у хворих на ЦД на стадії препатології та може бути рекомендованим для діагностики й моніторингу хворих на Цд.

\section{ЛIЕРАТУРA}

1. Балаболкин М.И. Сахарный диабет / М.И. Балаболкин // М.: Медицина, 1994. - 384 с.

2. Вардугина Н.Г. Вклад различных факторов риска в развитие ишемической болезни сердца у женщин в возрасте до 55 лет (клинико-ангиографическое и популяционное исследование) / Н.Г. Вардугина, Е.Г. Волкова // Рос. кардиол. журн. - 2004. - № 2. - С. 34-37.

3. Веселовська З.Ф. Порівняльна характеристика комп'ютерної кампіметрії та оптико-когерентної томографії у ранній діагностиці набряку макулярної ділянки у пацієнтів із діабетичною ретинопатією / З.Ф. Веселовська, Н.М.Веселовська // Клінічна ендокринологія та ендокринна хірургія. - 2005. - № 4(13). - С. 48-51.
4. Горбась І.М. Фактори ризику серцево-судинних захворювань: поширеність і контроль / І.М. Горбась // Український кардіологічний журнал. - 2004. - № 2. - С. 21-25.

5. Патогенез и лечение хронических осложнений сахарного диабета / А.С. Ефимов, Н.Д. Тронько, Л.К. Соколова [и др.] // Вісник фармакології та фармації. - 2007. - № 11. - С. 27-34.

6. Кваша О.О. Рекомендації з профілактики і лікування тютюнопаління / О.О. Кваша, І.М. Горбась, І.П. Смирнова // Здоров'я України. - 2010. № 2. - С. 34-36.

7. Коваленко В.Н. Артериальная гипертензия и системные метаболические нарушения в патогенезе гипертонической болезни / В.Н. Коваленко, Т.В. Талаева, В А. Шумаков, В.В. Братусь // Журнал НАМН України. - 2012. - Т. 18, № 1. - C. 40-54.

8. Либман Е.С. Современные позиции клинико-социальной офтальмологии / Е.С.Либман // Вестник офтальмологии. - 2004. - № 1. - С.10-12.

9. Либман Е.С. Слепота и инвалидность вследствие патологии органа зрения в России / Е.С. Либман, Е.В. Шахова // Вестник офтальмологии. - 2006. - № 1. - С. 35-37. 
10. Офтальмологічна допомога в Україні за 20062011 роки (аналітично-статистичний довідник). Київ. - 2012. - 184 с.

11. Тронько Н.Д. Современные проблемы диабетологии / Н.Д. Тронько // Журнал НАМН України. - 2000. - Т. 6, № 3. - С. 460-471.

12. Bloomgarden Z.T. Diabetic retinopathy / Z.T. Bloomgarden // Diabetes Care. - 2008. - Vol. 31, № 5. - P. 1080-1083.

13. Goya Wannamethee $S$. Physical activity and mortality in older men with diagnosed coronary heart disease / S. Goya Wannamethee, G. Shaper, M. Walker // Int. Med. J. - 2002. - Vol. 3. P. 201-207.

14. Levington $S$. The importance of cholesterol, blood pressure and smoking for coronary heart disease / S. Levington // Eur. Heart J. - 2003. Vol. 24. - P. 1703-1704.

15. Improved hypertension management and control: results from the health survey for England 1998 / P. Primatesta, M. Brookes, N.R. Pouler [et al.] // Hypertension. - 2001. - Vol. 38. - P. 827-832.

\section{РЕЗЮМЕ}

Факторы риска сосудистой патологии органа зрения у больных сахарным диабетом Н.Н. Веселовская

В работе определяли факторы риска развития сосудистой патологии у больных СД по данным ком- плексного офтальмологического и клинического обследования 120 больных сахарным диабетом 2-го типа и 20 практически здоровых лиц. Установлено, что нестабильный уровень глюкозы натощак, повышение уровней холестерина, лПнП, триглицеридов и коэффициента атерогенности при повышении HbA1c, АД, ИМТ в условиях недостаточной физической активности и нервного напряжения приводят к функциональным нарушениям макулярной зоны сетчатки и повышают риск развития сосудистой патологии органа зрения.

Ключевые слова: факторы риска, сахарный диабет, сетчатка, оптическая когерентная ретинальная томография.

\section{SUMMARY}

Risk factors of vascular pathology of the eye in diabetic patients

\section{N. Veselovskaya}

The paper reveals risk factors of vascular eye pathology in the diabetic patients on the base of ophthalmic and general examination 120 diabetic (type 2) and 20 healthy people. It was estimated that unstable level of blood sugar, increase of cholesterol, LPLW, triglyceride, $\mathrm{KA}$ and increase of on the $\mathrm{HbA} 1 \mathrm{c}$, blood pressure, BPIMB with low physical activity and tense anxiety complicated with functional disorders of macula and increase the risk of retinal eye pathology in diabetic patients.

Key words: risk factors, diabetes, retina, optical coherent retinal tomography. 